\title{
Influence of exogenous glutathione (GSH), as stressfactor, on the activity of lysosome enzymes in some organs of mice
}

\begin{abstract}
Summary
The studies were carried on 30 random 8-week old Swiss male mice. The mice of I group received peritoneally $100 \mu \mathrm{g} / \mathrm{g}$ b.w. of reduced glutathione (GSH) in $250 \mu \mathrm{l} 0.9 \% \mathrm{NaCl}$, II group $200 \mu \mathrm{g} / \mathrm{g}$ of GSH in $250 \mu \mathrm{l} 0.9 \%$ $\mathrm{NaCl}$ and mice of III control group received $250 \mu \mathrm{l}$ of $0.9 \% \mathrm{NaCl}$. In the lysosomal fraction of the liver, kidney and the skeletal muscle the activity of nine lysosomal enzymes were estimated. GSH injections caused in the liver a statistically confirmed increase of activity of estimated hydrolases, only the activity LL decreased significantly and NAGL did not change. After injection of both GSH doses increased significantly the activity LAP, Cat. D and L, AP, BGAL, BGLU and NAGL in the kidney. After injection $200 \mu \mathrm{g} / \mathrm{g}$ of GSH increased significantly activity AAP but an activity EL and LL decreased. In the skeletal muscle was observed a statistically confirmed increase of AP, LL, BGAL and NAGL activity, only the BGLU and Cat. D and L (after $100 \mu \mathrm{g} / \mathrm{g}$ dose) activity decreased.
\end{abstract}

Key Words: glutathione, kidney, liver, lysosomal enzymes, mice, muscle

\section{Zusammenfassung}

Titel der Arbeit: Einfluss von exogenem Glutathion als Stressfaktor auf die Aktivität der lysosomalen Enzyme in der Leber, Niere und im Muskel bei Mäusen

Nach $100 \mu \mathrm{g} / \mathrm{g}$ und $250 \mu \mathrm{g} / \mathrm{g}$ (Körpergewicht) Glutathioninjektion (GSH) wurde in der Leber eine Zunahme der lysosomalen Hydrolasenaktivität (ausgenommen lysosomale Lipase LL, welche sich verminderte) beobachtet. In der Niere erhöhte sich die Aktivität von LAP, Kat. D und L, AP, BGAL, BGLU und NAGL Enzymen. Im Muskel erhöhte sich die AP, LL, BGAL und NAGL Aktivität während sich BGLU, KAT D und L (nach 100 $\mu \mathrm{g} / \mathrm{g}$ Dosis) verminderten.

Schlüsselwörter: Glutathion, Niere, Leber, lysosomale Enzyme, Maus, Muskel

\section{Introduction}

Glutathione (L- $\gamma$-glutamyl-L-cysteinyl-glycine; GSH) has emerged to be one of the most fascinating molecules present in all animal cells often in quite high $(\mathrm{mM})$ concentrations. It is known to have multifaceted physiological functions including: antioxidant defense and detoxification of electrophilic xenobiotics (SIES, 1999); modulation of redox regulated signal transduction and gene expression (ITO et al., 1998); storage and transport of cysteine (SCHOFFNER et al., 1995); regulation of cell proliferation (HUANG et al., 1998); regulation of immune response (NAKAGAWA and RUDENSKY, 1999). The glutathione status may be used as a biological marker of aging (NOKATA et al., 1996). The ratio of GSH/GSSG is used as an index of the oxidative stress and may be the exponent of the organism's homeostasis (SAGARA et al., 1998). The function of several physiological proteins, including cellular enzymes and signaling molecules, is regulated by thiol-disulfide exchange between protein thiols and GSH mainly (FREEMAN et al., 1997). It was observed that oxidative 
processes determined in sarcoplasmic and myofibillar proteins could be respectively implicated in meat colour stability (myoglobin autooxidation) and tenderness changes during maturation of meat (RENERRE et al., 1996).

Lysosomes are membrane-bound organelles with an acidic internal milieu containing hydrolytic enzymes for degradation of proteins, lipids, nucleic acids and saccharides. The lysosomal compartment has multiple functions and it may be indicator of adaptative abilities (HICKS, 1995). It is known that lysosomes are especially sensitive to oxidative stress (LI et al., 1998). It was investigated that hydroxyl radicals destabilize the lysosomal membranes and thereby cause leakage of lysosomal enzymes to the cytosol with ensuing cellular degeneration or even death (HELLQUIST et al., 1997; ÖLLINGER, 2000).

The aim of this study was in connection with these data to investigate the influence of exogenous glutathione (GSH) on the activity of lysosomal hydrolases in hepatocytes, kidney and skeletal muscle of mice.

\section{Material and Methods}

The studies were carried out on 30 Swiss male mice of body weight $20-22$ g, aged 8 weeks, chosen at random from the population maintained at the Institute of Genetics and Animal Breeding, Polish Academy of Sciences in Jastrzębiec. The animals were kept in standard cages of the farm at temperature $22{ }^{\circ} \mathrm{C}$, under 12 hours of light and 12 hours of darkness. They were fed with a homogenous industrial fodder $(16 \%$ of protein) made by Animal Food Company in Łomna near Warsaw. The fodder and the water were available ad libitum.

The animals were divided into three groups, 10 mice in each. GSH solved in $0.9 \%$ $\mathrm{NaCl}$ solution was administered by peritoneal injection $-100 \mu \mathrm{g} / \mathrm{g}$ of body weight in $250 \mu \mathrm{l}$ of solution for group I and $200 \mu \mathrm{g} / \mathrm{g}$ of body weight in $250 \mu \mathrm{l}$ of solution for group II. Animals of group III, treated as control, received an injection of $250 \mu 1$ of $0.9 \% \mathrm{NaCl}$ (pure).

All the injections were performed over a period of 7 days, twice daily, at 8.30 a.m. and 4.30 p.m.

After decapitation operated, 16 hours after last injection, immediately the liver, kidney and skeletal muscle of left thigh were taken and subjected to perfusion in $0.9 \% \mathrm{NaCl}$ solution at $+5^{\circ} \mathrm{C}$. After grinding tissues were placed in a $0.1 \mathrm{M}$ phosphate buffer, $\mathrm{pH}$ 7.0 , in ratio $1 \mathrm{~g} / 6 \mathrm{ml}$. Next, the liver and the kidney were homogenized in the Potter homogenizer with a teflon piston and the skeletal muscle was homogenized with a glass piston at 200 rotations/min. with four up-down movements. These homogenates were centrifuged at Sorvall centrifuge for 10 minutes at $3500 \mathrm{rpm}$. and again for 20 minutes at $14000 \mathrm{rpm}$. The precipitate containing lysosomes was diluted in a $0.1 \mathrm{M}$ phosphate buffer, $\mathrm{pH} 6.0$ with Triton X-100 and finally frozen at $-20^{\circ} \mathrm{C}$. The clear supernatant was subjected to determination of the activities of lysosomal enzymes.

In the lysosomal fractions of the liver, the kidney and the skeletal muscle was determine the activity: alanylaminopeptidase (AAP - E.C. 3.4.11.2); leucylaminopeptidase (LAP - E.C. 3.4.11.1); cathepsin D and L (Cat. D and L - E C. 3.4.23.5); acid phosphatase (AP - E.C. 3.1.3.2); lysosomal esterase (EL - E.C. 3.1.1.2); lysosomal lipase (LL - E.C. 3.1.1.13); beta - galactosidase (BGAL - E.C. 3.2.1.23); beta - glucosidase (BGLU - E.C. 3.2.1.21); N-acetyl-beta-glucosaminidase (NAGL E.C. 3.2.1.30). 
The activity of AP, EL, LL, BGAL, BGLU and NAGL was determined spectrophotometrically as 4-nitrophenyl derivatives at $420 \mathrm{~nm}$ according to BARRETT's and HEATH's micro-method (1972). The activity of LAP and AAP was determined spectrophotometrically as Fast Blue BB salt (4-benzoyloamino-2.5diethoxybenzene-diazonium chloride) derivatives at $540 \mathrm{~nm}$ according to the method of MC DONALD and BARRETT (1986). The activity of cathepsin D and L was determined spectrophotometrically as $2 \%$ azocasein in 6 mol urea derivatives at 366 $\mathrm{nm}$ according to the method of LANGNER et al. (1973). Spectrophotometer Lambda Bio 20/1998 (Perkin Elmer) was used. The reduced glutathione (GSH) and substrates for enzyme and protein determinations were purchased from SIGMA.

In the lysosomal fractions the protein concentration was determined by the LOWRY's method modified by KIRSCHKE and WIEDERANDERS, (1984). The activity of lysosomal hydrolases was expressed in nmol/mg of protein/hour. Moreover we have determined GSH level 4 and 16 hours after injection according to Ellman's method (1959) in the liver of 10 control mice which were peritoneally injected with $0.9 \%$ solution of $\mathrm{NaCl}$ and 10 experimental animals injected with solution of $100 \mu \mathrm{g} / \mathrm{g} \mathrm{b} . \mathrm{w}$. of GSH.

The results obtained were analysed by analysis of variance.

This experiment has been realized according to the agreement of Institute Ethic Commission for Animal Research.

Results

The results are presented in Tables 1-5. The percentage changes of the activity were calculated accepting values obtained for control animals as $100 \%$.

Table 1

The activity (LSM \pm SEM) and percentage changes of lysosomal enzymes (nmol/ mg of protein/ hour) in the liver of mice after GSH injection; ( $\mathrm{n}$ in each subgroup $=10$ )

\begin{tabular}{|c|c|c|c|c|c|c|}
\hline & \multicolumn{2}{|l|}{ Control } & \multicolumn{3}{|c|}{ Experimental groups } & \multirow[b]{2}{*}{$\%$} \\
\hline Enzymes & $0,9 \% \mathrm{NaCl} \quad(\mathrm{C})$ & $\%$ & $100 \mu \mathrm{g} / \mathrm{g}$ GSH (G1) & $\%$ & $200 \mu \mathrm{g} / \mathrm{g}$ GSH (G2) & \\
\hline AAP & $113.42 \pm 6.09$ & 100 & $164.77 \pm 7.53$ & 145 & $212.50 \pm 12.19$ & 187 \\
\hline LAP & $73.41 \pm 2.85$ & 100 & $361.25 \pm 17.18$ & 492 & $390.75 \pm 17.03$ & 532 \\
\hline $\begin{array}{c}\text { Cathepsin } \\
\text { D and L }\end{array}$ & $16.89 \pm 0.88$ & 100 & $26.62 \pm 0.91$ & 158 & $21.82 \pm 0.71$ & 129 \\
\hline AP & $2648.83 \pm 71.92$ & 100 & $3177.47 \pm 94.58$ & 120 & $3738.56 \pm 82.28$ & 141 \\
\hline EL & $707.39 \pm 26.61$ & 100 & $1346.07 \pm 46.66$ & 190 & $1447.67 \pm 44.37$ & 205 \\
\hline LL & $1972.82 \pm 89.46$ & 100 & $1685.17 \pm 93.13$ & 85 & $1293.79 \pm 49.44$ & 66 \\
\hline BGAL & $162.97 \pm 5.20$ & 100 & $208.22 \pm 10.02$ & 128 & $215.99 \pm 7.34$ & 133 \\
\hline BGLU & $118.89 \pm 5.48$ & 100 & $227.23 \pm 10.30$ & 191 & $219.03 \pm 8.15$ & 184 \\
\hline NAGL & $1499.52+65.08$ & 100 & $1400.10 \pm 67.46$ & 93 & $1417.05 \pm 77.86$ & 95 \\
\hline
\end{tabular}

Table 1 informs that after both GSH doses in the liver increased significantly an activity of all studied lysosomal enzymes with the exception NAGL [93\% and 95\%]. Only the activity LL decreased significantly [ $85 \%$ and $66 \%]$.

In kidney (Table 2) was observed a significant increase of activity LAP, Cat. D and L, AP, BGAL, BGLU and NAGL. The larger GSH dose caused a significant increase of AAP activity and the decrease of EL and LL activity. 
Table 2

The activity $(\mathrm{LSM} \pm \mathrm{SEM})$ and percentage changes of lysosomal enzymes (nmol/ mg of protein/ hour) in kidney of mice after GSH injection; ( $\mathrm{n}$ in each subgroup $=10$ )

\begin{tabular}{|c|c|c|c|c|c|c|}
\hline & \multicolumn{2}{|l|}{ Control } & \multicolumn{3}{|c|}{ Experimental groups } & \multirow[b]{2}{*}{$\%$} \\
\hline Enzymes & $\begin{array}{c}0,9 \% \mathrm{NaCl} \\
\text { (C) }\end{array}$ & $\%$ & $\begin{array}{c}100 \mu \mathrm{g} / \mathrm{g} \text { GSH } \\
(\mathrm{G} 1)\end{array}$ & $\%$ & $\begin{array}{c}200 \mu \mathrm{g} / \mathrm{g} \text { GSH } \\
(\mathrm{G} 2)\end{array}$ & \\
\hline AAP & $1426.33 \pm 68.17$ & 100 & $1323.62 \pm 76.06$ & 93 & $2983.70 \pm 71.45$ & 209 \\
\hline LAP & $1356.05 \pm 63.57$ & 100 & $2165.97 \pm 72.55$ & 160 & $1808.68 \pm 41.45$ & 133 \\
\hline $\begin{array}{l}\text { Cathepsin } \\
\text { D and L }\end{array}$ & $9.86 \pm 0.36$ & 100 & $12.94 \pm 0.46$ & 131 & $13.65 \pm$ & 138 \\
\hline AP & $2150.30 \pm 90.58$ & 100 & $8333.86 \pm 604.51$ & 388 & $5759.62 \pm 291.57$ & 268 \\
\hline EL & $836.88 \pm 21.80$ & 100 & $781.24 \pm 31.96$ & 93 & $667.95 \pm 19.40$ & 80 \\
\hline LL & $1481.57 \pm 65.69$ & 100 & $1482.18 \pm 77.01$ & 100 & $934.86 \pm 47.83$ & 63 \\
\hline BGAL & $153.73 \pm 5.65$ & 100 & $213.16 \pm$ & 139 & $264.66 \pm 13.08$ & 172 \\
\hline BGLU & $87.99 \pm 3.20$ & 100 & $134.19 \pm$ & 153 & $126.10 \pm$ & 143 \\
\hline NAGL & $1431.30 \pm 45.84$ & 100 & $1769.61 \pm 71.49$ & 124 & $2047.16 \pm 67.66$ & 143 \\
\hline
\end{tabular}

Table 3

The activity (LSM \pm SEM) and percentage changes of lysosomal enzymes (nmol/ mg of protein/ hour) in the muscle of mice after GSH injection; ( $\mathrm{n}$ in each subgroup $=10$ )

\begin{tabular}{|c|c|c|c|c|c|c|}
\hline \multirow[b]{2}{*}{ Enzymes } & \multicolumn{2}{|l|}{ Control } & \multicolumn{3}{|c|}{ Experimental groups } & \multirow[b]{2}{*}{$\%$} \\
\hline & $\begin{array}{c}0,9 \% \mathrm{NaCl} \\
\text { (C) }\end{array}$ & $\%$ & $\begin{array}{c}100 \mu \mathrm{g} / \mathrm{g} \text { GSH } \\
(\mathrm{G} 1)\end{array}$ & $\%$ & $\begin{array}{c}200 \mu \mathrm{g} / \mathrm{g} \text { GSH } \\
(\mathrm{G} 2)\end{array}$ & \\
\hline AAP & $85.86 \pm 4.31$ & 100 & $75.63 \pm 3.86$ & 88 & $86.07 \pm 4.76$ & 100 \\
\hline LAP & $57.76 \pm 2.57$ & 100 & $62.01 \pm 2.95$ & 107 & $61.06 \pm 2.82$ & 106 \\
\hline $\begin{array}{c}\text { Cathepsin } \\
\text { D and L }\end{array}$ & $3.00 \pm 0.09$ & 100 & $2.33 \pm 0.13$ & 78 & $3.56 \pm 0.20$ & 119 \\
\hline AP & $426.57 \pm 12.98$ & 100 & $537.09 \pm 23.33$ & 126 & $629.53 \pm 25.97$ & 148 \\
\hline EL & $107.42 \pm 4.17$ & 100 & $109.79 \pm 3.42$ & 102 & $121.96 \pm 5.02$ & 114 \\
\hline LL & $3.33 \pm 0.20$ & 100 & $18.02 \pm 0.89$ & 541 & $8.41 \pm 0.43$ & 253 \\
\hline BGAL & $4.73 \pm 0.21$ & 100 & $6.22 \pm 0.28$ & 131 & $7.77 \pm 0.44$ & 164 \\
\hline BGLU & $10.62 \pm 0.57$ & 100 & $9.42 \pm 0.39$ & 89 & $9.00 \pm 0.21$ & 85 \\
\hline NAGL & $207.84+10.64$ & 100 & $252.56 \pm 14.73$ & 122 & $277.51+12.06$ & 134 \\
\hline
\end{tabular}

Table 4

The GSH concentration ( $\mu \mathrm{M} / \mathrm{mg}$ of protein) in the liver of control and experimental mice 4 and 16 hours after of exogenous GSH injection (100 $\mu \mathrm{g} / \mathrm{g}$ b.w.); ( $\mathrm{n}$ in each group $=10)$

\begin{tabular}{lll}
\hline Injection Control & Experimental groups
\end{tabular}

\begin{tabular}{|c|c|c|c|c|}
\hline & $4 h$ & $16 \mathrm{~h}$ & $4 \mathrm{~h}$ & $16 \mathrm{~h}$ \\
\hline $\begin{array}{l}0.9 \% \mathrm{NaCl} \\
(250 \mu \mathrm{l})\end{array}$ & $\begin{array}{c}12.2^{1} \\
11.6-12.9 \\
(100 \%)\end{array}$ & $\begin{array}{c}11.7^{2} \\
10.9-12.1 \\
(96 \%)\end{array}$ & & \\
\hline $\begin{array}{l}\text { GSH } \\
(250 \mu \mathrm{l})\end{array}$ & & & $\begin{array}{c}21.1^{1} \\
16.7-23.5 \\
(173 \%)\end{array}$ & $\begin{array}{c}15.2^{2} \\
14.6-15.8 \\
(130 \%)\end{array}$ \\
\hline
\end{tabular}

In the skeletal muscle (Table 3) after administration of first and second GSH dose was observed an increase activity of AP, LL, BGAL and NAGL. The smaller dose decreased of Cat. D and L [78\%] activity but the larger GSH dose increased it [119\%] 
and EL activity [114\%] somewhat unsignificantly. BGLU activity decreased significantly after two doses of GSH injection [89\% and $85 \%$ ].

Table 4 revealed, that GSH concentration in the liver of control mice after $\mathrm{NaCl}$ injections maintained on equal level after 4 and 16 hours [12.2 and $11.7 \mu \mathrm{M}$ ] but in experimental animals it increased to $173 \%$ after 4 hours and to $130 \%$ after 16 hours [21.1 and $15.2 \mu \mathrm{M}]$.

Table 5

The analysis of variance for the examined lysosomal enzyme activities

\begin{tabular}{|c|c|c|c|c|c|c|c|c|c|}
\hline Enzyme & AAP & LAP & CAT D,L & AP & EL & $\mathrm{LL}$ & BGAL & BGLU & NAGL \\
\hline $\begin{aligned} \text { Liver } \\
\text { C - G1 }\end{aligned}$ & & & & & & & & & \\
\hline MS & 13184.6 & 414248 & 472.59 & 1397338 & 2039574 & 413718 & 10240.5 & 58657.8 & 49426.7 \\
\hline F value & 16.33 & 209.42 & 67.03 & 20.07 & 126.06 & 6.49 & 16.93 & 86.91 & 1.00 \\
\hline $\begin{array}{l}F \\
C-G 2\end{array}$ & $0.0004 * * *$ & $0.0001 * * *$ & $0.0001 * * *$ & $0.0001 * * *$ & $0.0001 * * *$ & $0.0169 *$ & $0.0003 * * *$ & $0.0001 * * *$ & 0.3265 \\
\hline MS & 49080.3 & 503520 & 121.43 & 5937612 & 2740102 & 2305395 & 14056.7 & 50144.1 & 34011.5 \\
\hline F value & 60.77 & 254.55 & 17.22 & 85.28 & 169.36 & 36.17 & 23.24 & 74.26 & 0.69 \\
\hline $\begin{array}{l}F \\
\text { G1 - G2 }\end{array}$ & $0.0001 * * *$ & $0.0001 * * *$ & $0.0003 * * *$ & $0.0001 * * *$ & $0.0001 * * *$ & $0.0001 * * *$ & $0.0001 * * *$ & $0.0001 * * *$ & 0.4144 \\
\hline MS & 11388.4 & 4352.13 & 114.91 & 1574099 & 51614.8 & 765876 & 301.55 & 335.87 & 1436.34 \\
\hline F value & 14.10 & 2.20 & 16.3 & 22.61 & 3.19 & 12.02 & 0.50 & 0.50 & 0.03 \\
\hline $\mathrm{F}$ & $0.0008^{* * *}$ & 0.1496 & $0.0004 * * *$ & $0.0001 * * *$ & 0.0853 & $0.0018 * *$ & 0.4862 & 0.4867 & 0.866 \\
\hline $\begin{array}{l}\text { Kidne } \\
\text { C - G1 }\end{array}$ & & & & & & & & & \\
\hline MS & 52754.9 & 3279852 & 47.49 & 1911822 & 15477.9 & 1.88 & 17659 & 10670.3 & 572289 \\
\hline F value & 1.02 & 89.27 & 26.86 & 125.05 & 2.48 & 0.001 & 21.95 & 80.01 & 14.56 \\
\hline $\begin{array}{l}\mathrm{F} \\
\mathrm{C}-\mathbf{G} \mathbf{2}\end{array}$ & 0.3218 & $0.0001 * * *$ & $0.0001 * * *$ & $0.0001 * * *$ & 0.127 & 0.9947 & $0.0001 * * *$ & $0.0001 * * *$ & $0.0007 * * *$ \\
\hline MS & 1212697 & 1024383 & 71.74 & 6513573 & 142675 & 1494465 & 61527.3 & 726101 & 1896418 \\
\hline F value & 234.16 & 27.88 & 40.57 & 42.61 & 22.86 & 35.77 & 76.47 & 54.45 & 48.26 \\
\hline $\begin{array}{l}F \\
\text { G1 - G2 }\end{array}$ & $0.0001 * * *$ & $0.0001 * * *$ & $0.0001 * * *$ & $0.0001 * * *$ & $0.0001 * * *$ & $0.0001 * * *$ & $0.0001 * * *$ & $0.0001 * * *$ & $0.0001 * * *$ \\
\hline MS & 1377942 & 638270 & 2.49 & 3313378 & 64167.5 & 1497818 & 13261.8 & 327.1 & 385153 \\
\hline F value & 266.07 & 17.37 & 1.41 & 21.67 & 10.28 & 35.85 & 16.48 & 2.45 & 9.80 \\
\hline $\begin{array}{l}F \\
\text { Muscle }\end{array}$ & $0.0001 * * *$ & $0.0003 * * *$ & 0.2455 & $0.0001 * * *$ & $0.0034 * *$ & $0.0001 * * *$ & $0.0004 * * *$ & 0.129 & $0.0042 * *$ \\
\hline C - G1 & & & & & & & & & \\
\hline MS & 523.78 & 90.40 & 2.26 & 61072.2 & 28.27 & 1078.5 & 11.09 & 7.20 & 10003 \\
\hline F value & 2.80 & 1.17 & 10.61 & 13.21 & 0.16 & 320.55 & 10.51 & 4.14 & 6.31 \\
\hline $\mathrm{F}$ & 0.106 & 0.2896 & $0.0030 * *$ & $0.0012 * *$ & 0.6957 & $0.0001 * * *$ & $0.0031 * *$ & 0.0518 & $0.0183^{*}$ \\
\hline C - G2 & & & & & & & & & \\
\hline MS & 0.21 & 54.35 & 1.56 & 205948 & 1058.22 & 129.23 & 46.06 & 13.09 & 24268.8 \\
\hline F value & 0.001 & 0.70 & 7.34 & 44.54 & 5.85 & 38.41 & 43.68 & 7.52 & 15.30 \\
\hline $\begin{array}{l}F \\
\text { G1 - G2 }\end{array}$ & 0.9738 & 0.4096 & $0.0116^{*}$ & $0.0001 * * *$ & $0.02 *$ & $0.0001 * * *$ & $0.0001 * * *$ & $0.0107 *$ & $0.0006 * * *$ \\
\hline MS & 544.76 & 4.56 & 7.58 & 42719.3 & 740.5 & 461.09 & 11.95 & 0.87 & 3110.3 \\
\hline F value & 2.91 & 0.06 & 35.6 & 9.24 & 4.09 & 137.04 & 11.34 & 0.50 & 1.96 \\
\hline $\mathrm{F}$ & 0.0995 & 0.8101 & $0.0001 * * *$ & $0.0052 *$ & 0.053 & $0.0001 * * *$ & $0.0023 * *$ & 0.4846 & 0.1728 \\
\hline
\end{tabular}

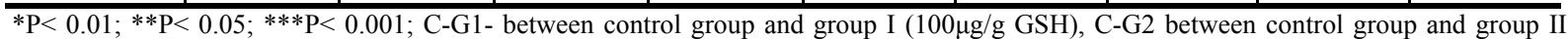
(200 $\mu \mathrm{g} / \mathrm{g} \mathrm{GSH}), \mathrm{G} 1-\mathrm{G} 2-$ between group I and group II

We can see from Table 5 that $\mathrm{F}$ values for the majority of the examined enzymes were statistically high confirmed $[\mathrm{P}<0.001]$. 


\section{Discussion}

The intracellular synthesis of glutathione and its extracellular and intracellular degradation take place by the reactions of the $\gamma$-glutamyl cycle and a system of specific enzymes (KELLY, 1999). The liver is very active in its synthesis de novo. It is limited by $\gamma$-glutamylcysteine synthetase (GCS) activity. However, the enzymatic capacity of the kidney to synthesis and degradation of the glutathione may be higher than that in the liver. Glutathione may be exported from the liver to the plasma and another tissues and it is controled by $\gamma$-glutamyltranspeptidase (WANG et al., 1998).

Supplementation of free GSH has to cause inhibition of GCS by high GSH level (MEISTER, 1991). However, several studies have reported that GSH administration can increase cysteine transport into the cells and it may change the enzymatic control of cell (LEEUWENBURGH and JI, 1998). Besides it has been suggested that the esters $\mathrm{N}$-acetyl cysteine and iso-propyl-SG are easy transported into the living cells without specific transporter and can be the reductants as same as reduced glutathione (ENKVETCHAKUL and BOTTLE, 1995).

The results obtained indicate that the administration of exogenous GSH (both doses) caused the significant differences in the activity of the enzymes examined as compared to the control values. The studies conducted by KOLATAJ et al. (1998), LOMBARDO (1996) indicate, that the lysosomal system constitutes the defence lines of the cells against stressors and it responds to disturbances in cell homeostasis.

Same studies indicate that sulphydryl groups have protective effect at lysosomal membrane and lysosomal sulphate transport is dependent upon these groups (BRUNK, et al., 1996; CHOU et al., 1998).

Differences in the activity of lysosomal hydrolases estimated in the control animals were the result of their tissue origin (FERLAND et al., 1990). In all estimated organs the biggest activity was observed for AP. This enzyme is typical for the lysosomal fraction (CHEN and CHEN, 1988).

It has been reported that GSH is transported out of renal proximal tubular across the brush-border membrane by a membrane potential-sensitive carrier (LASH et al., 1998). The highest activity of AAP and LAP was observed in the kidney, where they are placed first of all in the epithelium of renal tubule and are included in protein resorption from the tubuli fluid (MANTLE, 1991). NAGL is a hydrolase, which participates in the breakdown of glycoproteins. The activity of this enzyme proved higher in the liver and kidney than in the muscle. Some studies have reported that the GSH depletion can modulate processes of glycosylation (mainly proteins) (JAIN, 1998) and different doses of GSH can change activity of estimated lysosomal glycosydases.

Beside other numerous functions, the cell uses GSH for importing of $\gamma$ - glutamylaminoacids and for the intracellular transport of cysteine, what among others, may cause an increase of the cathepsin activity. An increase of the proteolytic activity is linked with the activity of cathepsins and aminopeptidases too. Any type of stress burden results the significant fluctuations of cathepsin activity (SCHMIDT et al., 1993).

Activity of lysosomal esterases is an indicator of the cell lipolytic ability too. An increase of reduction processes caused by the administered GSH may decrease the rate of $\beta$ - oxidation of fatty acids what, in turn, may result a decrease LL and EL activity in the kidney and LL in the liver (TIEN et al., 1982). 
An exogenous reduced glutathione (GSH), independent from doses, introduced to an organism can demonstrate that the lysosomal enzymatic system plays an important role in the adaptative physiological response. These observed changes of the activity of examined lysosomal enzymes are probably on the basis of increasing of reducing environment in the cell. They are actually difficult to the explanation but they can have the pharmacological and physiological importance. It was also demonstrated a certain "organ specificity". The enzyme activity changes after GSH administration were somewhat differently in liver, kidneys and muscles, but we do not yet know the reasons for this differentiation.

\section{References}

BARRETT, A. J.; HEATH, M.F.:

Lysosomal enzymes. In: Lysosomes; A Laboratory Handbook. DINGLE, J. T. (Ed), North-Holland Publ. Co., Amsterdam, ( 1972 ), 19-135

BRUNK, U.T.; ZHANK, H.; ROBERG, K.; ÖLLINGER K.:

Lethal hydrogen peroxide toxicity involves lysosomal iron-catalyzed reactions with membrane damage. Redox Report 1(1996), 267-277

CHEN, C.H.; CHEN, S.C.:

Evidence of acid phosphatase in the cytoplasma as distinct entity. Arch. Biochem. Biophs. 262 (1988), 427-438

CHOU, H.F.; PASSAGE, M.; JONAS, A.J.: Lysosomal sulphate transport is dependent upon sulphydryl groups. Biochem. J. 330 (1998), 713-717

ELLMAN, G.L.: Tissue sulfhydryl groups. Arch. Biochem. Biophys. 82 (1959), 70-77

ENKVETCHAKUL, B.; BOTTJE, W.G.: Influence of Diethyl Maleate and Cysteine on Tissue Glutathione and Growth in Broiler Chickens. Poultry Sci. 74 (1995), 864-873

FERLAND, G.; PERA, A.; AUDET, M.; TUCHWEBER, B.: Characterization of liver lysosomal enzyme activity in hepatocytes, Kupffer and endothelial cells during aging: effect of dietary restriction. Mech. Ageing Dev. 56 (1990), 143-154

FREEMAN, M.L.; HUNTLEY, S.A.; MEREDITH, M.J.; SENISTERRA, G.A.; LEPOCK, J.: Destabilization and denaturation of cellular protein by glutathione depletion. Cell Stress and Chaperones 2 (1997), 191-198

HELLQUIST, H.B.; SVENSSON, I.; BRUNK U.T.:

HICKS, J.J.: Oxidant-induced apoptosis: a consequence of lethal lysosomal leak. Redox Rep. 3 (1997), 65-70 Lysosomal system in hormonal mechanism. Ginecol. Obstet. Mex. 63 (1995), 68-73

HUANG, Z.Z.; LI, H.; CAI, J.; KUHLENKAMP, J.; KAPLOWITZ, N.; LU, S.C.: Changes in glutathione homeostasis during liver regeneration in the rat. Hepathology 27 (1998), 147153

ITO, H.; OKAMOTO, K.; KATO, K.:

Enhacement of expression of stress proteins by agents that lower the levels of glutathione in cells. Biochem. Biophys. Acta 1397 (1998), 223-230

JAIN, S.K.:

Glutathione and glucose-6-phosphate dehydrogenase deficiency can increase protein glycosylation. Free Rad. Biol. Med. 1 (1998), 197-201

KELLY, F.J.:

Glutathione: in Defence of the Lung. Food Chem. Toxicol. 37 ( 1999 ), 963- 966

KIRSCHKE, H.; WIEDERANDERS, B.:

Methoden zur Aktivitätsbestimmung von Proteinases. Martin-Luther-Universität, Halle-Wittenberg, Wissenschaftl. Beitr. Halle/Saale, (1984), 11-17

KOŁĄTAJ, A.; SOMMER, A.; WITEK, B.; NITRAY, J.; FLAK, P.:

The effect of exogenous glucose on the activity of lysosomal enzymes, the glucose and insulin concentration in the blood plasma of young bulls. Arch. Tierz., Dummerstorf 41 (1998), 371-377

LANGNER, J.; WAKIL, A.; ZIMMERMANN, M.; ANSORGE, S.; BOHLEY, H.; KIRSCHKE, H.; WIEDERANDERS, B.:

Aktivitätsbestimmung proteolytischer Enzyme mit Azokasein als Substrat. Acta Biol. Med. Germanica 31 (1973), 1-18 
LASH, L.H.; VISARIUS, T.M.; SALL, J.M.; QIAN, W.; TOKARZ, J.J.:

Cellular and subcellular heterogeneity of glutathione metabolism and transport in rat kidney cells. Toxicology 130 (1998), 1-15

LEEUWENBURGH, CG.; JI, L.L.:

Glutathione and glutathione ethyl ester supplementation of mice alter glutathione homeostasis during exercise. J. Nutr. 128 (1998), 2420-2427

LI, W.; YUAN, X. M.; BRUNK, U.T.:

OxLDL-induced macrophage cytotoxicity is mediated by lysosomal rupture and modified by intralysosomal redox-active iron. Free Rad. Res. 29 (1998), 389-398

LOMBARDO, A.; BAIRATI, C.; GOI, G.; ROGGI, C.; MACCARIANI, L.; BOLLINI, D.; BURLINA, A.: Plasma lysosomal glycohydrolases in a general population. Clin. Chim. Acta 247 (1996), 39-49

MANTLE, D.:

Characterization of dipeptidyl and tripeptydyl aminopeptidases in human kidney soluble fraction. Clin. Chim. Acta 196 (1991), 135-142

MC DONALD, J.K.; BARRETT A.J.:

Exopeptidases. In: Mammalian Proteases: A Glossary and Bibliography, 2, eds. London, UK, Academic

MEISTER, A.: Press (1986), 111-144

Glutathione deficiency produced by inhibition of its synthesis and its reversal: applications in research and therapy. Pharmacol. Ther.51 (1991), 155-194

NAKAGAWA, T.Y.; RUDENSKY, A.Y.:

The role of lysosomal proteinases in MHC class II-mediated antigen processing and presentation. Immunological Rev. 172 (1999), 121-129

NOKATA, K.; KAWASE, M.; OGINO, S.; KINOSHITA, C.; MURATA, H.; SAKAUE, T.; OGATA, K.; OHMORI, S.:

Effect of age on levels of cysteine, glutathione and related enzyme activities in livers of mice and rats and attempt to replenish hepatic glutathione level of mouse with cysteine derivatives. Mech. Ageing Develop. 90 (1996), 195- 207

ÖLLINGER, K.:

Inhibition of cathepsin D prevents free-radical-induced apoptosis in rat cardiomyocytes. Arch. Biochem. Biophys., 373 (2000), 346-351

RENERRE, M.; DUMONT, F.; GATELLIER, PH.:

Antioxidant Enzyme Activities in Beef in Relation to Oxidation of Lipid and Myoglobin. Meat Sci. 43 (1996), 111-121

SAGARA, Y.; DARGUSCH, R.; CHAMBERS, D.; DAVIS, J.; SCHUBERT, D.; MAHER, P.:

Cellular mechanisms of resistance to chronic oxidative stress. Free Radical Biol. Med. 24 (1998), 13751390

SCHMIDT, M.; KOŁĄTAJ, A.; BULLA J.:

Die lysosomalen Enzyme der Leukozyten als Adaptationsindikator einiger Stresseinwirkungen beim Schwein. Beiträge, Kolloquium „Adaptation bei Nutztieren” (Dummerstorf), 1 (1993), 3-11

SCHOFFNER, J. M.; VOLJAVEC, A. S.; DIXON, J.; KAUFMAN, A.; WALLACE, D. C.; MITCH, E. E.: Renal amino acid transport in adult with oxidative phosphorylation diseases. Kidney Int. 47 (1995), $1101-1107$

SIES, H.:

Glutathione and its role in cellular functions. Free Rad. Biol. Med. 27 (1999), 916-921

TIEN, M.; BUCHER, J. R.; AUST, S. D.:

Thiol-dependent lipid peroxidation. Biochem. Biophys. Res. Commun. 107 (1982), 279- 285

WANG, S.; BOTTJE, W.G.; CAWTHON, D.; EVENSON, C.; BEERS, K.; MC NEW, R.:

Hepatic export of glutathione and uptake of constituent amino acids, glutamate and cysteine in broilers in vivo. Poultry Sci. 77 ( 1998 ), 1556-1564

Received: 2000-11-27

Accepted: 2002-04-15

Author's address

Dr. ANNA ŚLIWA-JÓŹWIK, Dr. ARTUR JÓŹWIK, Prof. Dr. ADAM KOŁĄTAJ

Institute of Genetics and Animal Breeding, Polish Academy of Sciences, Jastrzębiec

05-552 Wólka Kossowska

Poland 